\begin{tabular}{|l|l|}
\hline $\begin{array}{l}\text { 2. To: (Receiving Organization) } \\
\text { Distribution }\end{array}$ & $\begin{array}{l}\text { 3. From: (Originating Organization) } \\
\text { PJ Brackenbury R3-73, 372-1776 }\end{array}$ \\
\hline $\begin{array}{l}\text { 5. Proj./Prog./Dept./Div.: } \\
\text { River Protection Projects (RPP) }\end{array}$ & $\begin{array}{l}\text { 6. Design Authority/Design Agent/Cog. Engr.: } \\
\text { TBD }\end{array}$ \\
\hline $\begin{array}{l}\text { 8. Originator Remark: } \\
\text { A summary of the available PUREX connector stress analyses and test } \\
\text { results which will form the bases for the Waste Eeed Delivery } \\
\text { mission is presented. Review and approval is requested. }\end{array}$
\end{tabular}

11. Receiver Remarks:

11A. Design Baseline Document? $\square$ Yes $\square$ No

\begin{tabular}{|c|c|c|c|}
\hline \multicolumn{4}{|c|}{ 4. Related EDT No.: } \\
\hline \multicolumn{4}{|c|}{ 7. Purchase Order No.: } \\
\hline \multicolumn{4}{|l|}{$N / A$} \\
\hline \multicolumn{4}{|c|}{ 9. Equip./Component No.: } \\
\hline \multicolumn{4}{|l|}{$\mathrm{N} / \mathrm{A}$} \\
\hline \multicolumn{4}{|c|}{ 10. System/B/dg./Facility: } \\
\hline \multicolumn{4}{|c|}{ River Protection } \\
\hline \multicolumn{4}{|c|}{ 12. Major Assm. Dwg. No.: } \\
\hline \multicolumn{4}{|c|}{$\mathrm{N} / \mathrm{A}$} \\
\hline \multirow{2}{*}{\multicolumn{4}{|c|}{$\begin{array}{l}\text { 13. Permit/Permit Application No.: } \\
\text { N/A }\end{array}$}} \\
\hline & & & \\
\hline \multirow{2}{*}{\multicolumn{4}{|c|}{$\begin{array}{l}\text { 14. Required Response Date: } \\
3-24-00\end{array}$}} \\
\hline & & & \\
\hline (F) & (G) & $(H)$ & (I) \\
\hline $\begin{array}{l}\text { Approval } \\
\text { Desig- } \\
\text { nator }\end{array}$ & $\begin{array}{l}\text { Reason } \\
\text { for Trans- } \\
\text { mittal }\end{array}$ & $\begin{array}{c}\text { Origi- } \\
\text { nator } \\
\text { Dispo- } \\
\text { stion }\end{array}$ & $\begin{array}{c}\text { Receiv- } \\
\text { er } \\
\text { Dispo- } \\
\text { sition }\end{array}$ \\
\hline $\mathrm{N} / \mathrm{A}$ & 1 & $z$ & - \\
\hline & & & \\
\hline & & & \\
\hline & & & \\
\hline & & & \\
\hline & & & \\
\hline & & & \\
\hline
\end{tabular}

KEY

Reason for Transmittal (G)

4. Review

5. Post-Review

6. Dist. (Receipt Acknow. Required)

Waste Feed Delivery

PUREX PROCESS CONNECTOR

DESIGN PRESSURE

SIGNATURE/DISTRIBUTION

(See Approval Designator for required signatures)

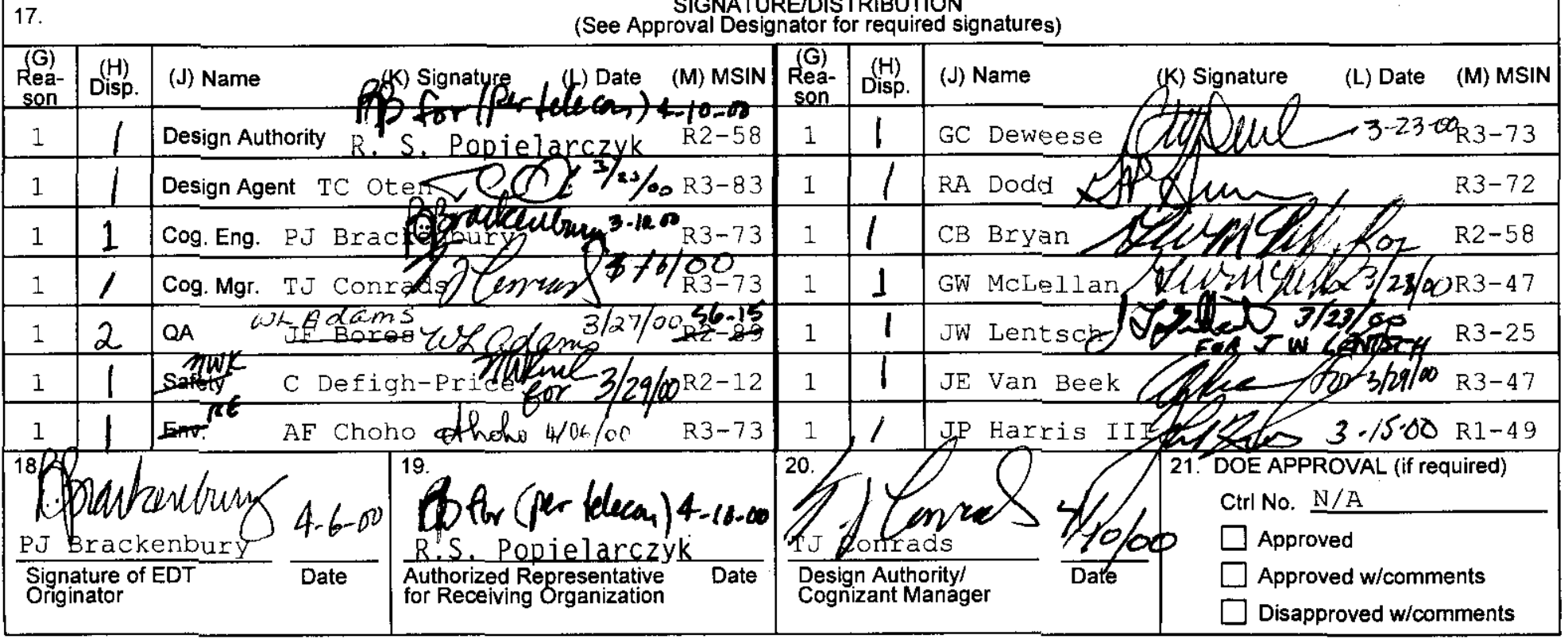

BD-7400-172-2 (10/97) 


\title{
Waste Feed Delivery PUREX PROCESS CONNECTOR DESIGN PRESSURE
}

\author{
P. J. Brackenbury \\ Numatec Hanford Corporation \\ Richland, WA 99352 \\ U.S. Department of Energy Contract DE-AC06-99RL14047
}

$\begin{array}{lll}\text { EDT/ECN: } & 628456 & \text { UC: } 721 \\ \text { Cost Center: } 6 \text { N100 } & \text { Charge Code: } 110310 \\ \text { B\&R Code: } & \text { EW3130000 } & \text { Total Pages: } 26 \text { (4/4/1/1/00 }\end{array}$

Key Words: PUREX Connector, Jumper, Design Pressure, Waste Feed Delivery systems, Project $W-521$

Abstract: The pressure retaining capability of the PUREX process connector is documented. A context is provided for the connector's current use within existing projects. Previous testing and structural analyses campaigns are outlined. The deficient condition of the current inventory of connectors and assembly wrenches is highlighted. A brief history of the connector is provided. A bibliography of pertinent references is included.

TRADEMARK DISCLAIMER. Reference herein to any specific commercial product, process, or service by trade name, trademark, manufacturer, or otherwise, does not necessarily constitute or imply its endorsement, recommendation, or favoring by the United States Government or any agency thereof or its contractors or subcontractors.

Printed in the United States of America. To obtain copies of this document, contact: Document Control Services, P.O. Box 950, Mailstop H6-08, Richland WA 99352, Phone (509) 372-2420; Fax (509) 376-4989.
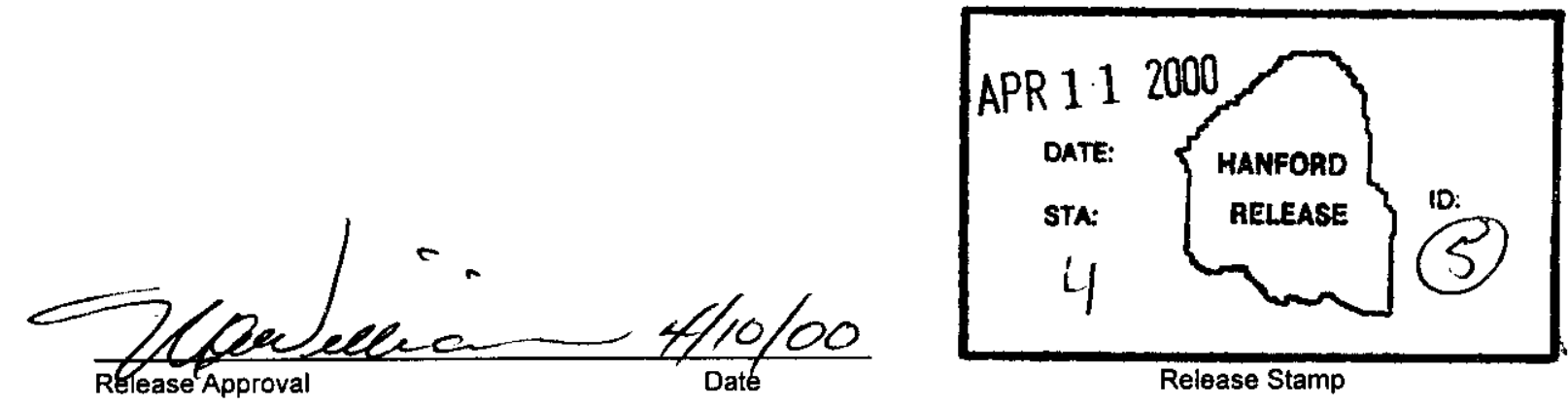

\section{Approved For Public Release}


RPP-5793

Revision 0

\section{Waste Feed Delivery \\ PUREX Process \\ Connector Design \\ Pressure}

Prepared for the U.S. Department of Energy

Assistant Secretary for Environmental Management

\section{CH2MHILL \\ Hanford Group, Inc.}

Richland, Washington

Contractor for the U.S. Department of Energy
Office of River Protection under Contract DE-AC06-99RL14047

Approved for Public Release; Further Dissemination Unlimited 
RPP-5793

Revision 0

\section{Waste Feed Delivery \\ PUREX Process Connector Design Pressure}

Prepared by:

P. J. Brackenbury

Numatec Hanford Corporation

Richland, Washington

Date Published

April 2000

\section{CH2MHILL \\ Hanford Group, Inc.}

P. O. Box 1500

Richland, Washington

Contractor for the U.S. Department of Energy

Office of River Protection under Contract DE-AC06-99RL14047

Approved for Public Release; Further Dissemination Unlimited 


\section{RPP-5793 REV 0}

\section{EXECUTIVE SUMMARY}

The documented basis for the ultimate pressure retaining capability of the venerable PUREX process connector with conventional gasket, in wide use at Hanford since 1953, is not readily retrievable. Emerging design pressure requirements demanded by Waste Feed Delivery Projects challenge the lack of documentation justifying the ultimate design pressure.

Analyses and testing in the recent past qualify the design of all sizes of conventionally sealed connectors to a design pressure of $2.76 \mathrm{MPa}\left(400 \mathrm{lbf} / \mathrm{in}^{2}\right.$ gauge) and a test pressure of $4.14 \mathrm{MPa}$ $\left(600 \mathrm{lbf} \mathrm{in}^{2}\right)$. Limited experience (SY-101 Level Mitigation Project and Evaporator Upgrades Project) also exists in which test pressures of $6.21 \mathrm{MPa}\left(900 \mathrm{lbf} / \mathrm{in}^{2}\right)$ were demonstrated. Any applications beyond the parameters require the appropriate analyses and testing.

Assembly stresses that must be achieved to effect an adequate seal to $6.21 \mathrm{MPa}\left(900 \mathrm{lbf} / \mathrm{in}^{2}\right)$ challenge the connector components. Knowing this, an alternate seal design, referred to as the Integral Seal Block (ISB) connector, was developed in support of two Hanford Site projects that were never built. The alternate seal design was subsequently applied in limited number to the low pressure supernate side of the Replacement Cross Site Transfer System (W-058 Project) and has seen successful "low pressure" service not exceeding $2.76 \mathrm{MPa}\left(400 \mathrm{lbf} / \mathrm{in}^{2}\right.$ gauge). However, all sizes of the ISB design were successfully tested at $200^{\circ} \mathrm{C}\left(400^{\circ} \mathrm{F}\right)$ with piping moments applied to $6.9 \mathrm{MPa}\left(1000 \mathrm{lbf} / \mathrm{in}^{2}\right.$ gauge). In all cases reported, assembly stresses were minimal in that the torque applied to the operating screw was $20 \%$ of the usual. When welded to new jumper piping, all sizes of the ISB connector would integrate successfully with existing nozzles and connector components. 


\section{RPP-5793 REV 0}

A brief history of the connector is given, the inventory management approach practiced in the recent past is described, and the deficient state of the existing connector components inventory is highlighted. Recommendations concerning the impact (assembly) wrenches, key to the success of the connector, also are included.

ES-ii 


\section{TABLE OF CONTENTS}

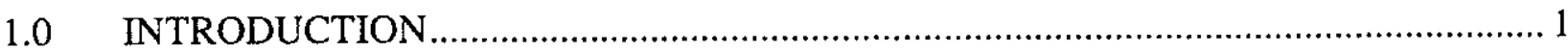

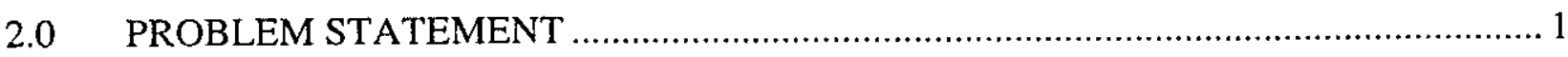

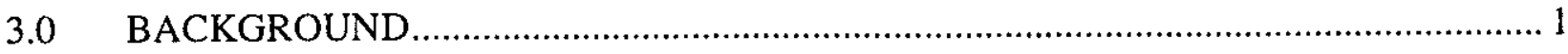

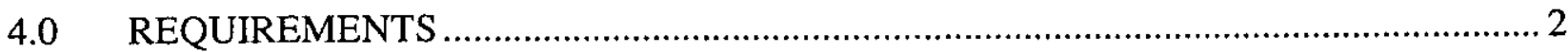

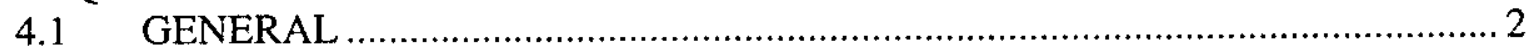

4.2 PROJECT-SPECIFIC REQUIREMENTS ................................................. 3

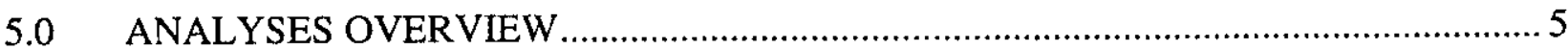

5.1 AGING WASTE TRANSFER LINES (PROJECT W-028) .............................. 5

5.2 HANFORD WASTE VITRIFICATION PLANT (PROJECT B-595) .................. 6

5.3 MULTIFUNCTION WASTE TANK FACILITY (PROJECT W-236A) ............. 6

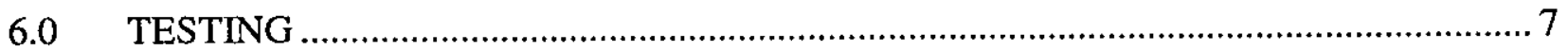

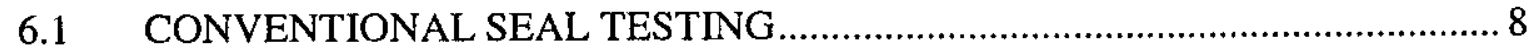

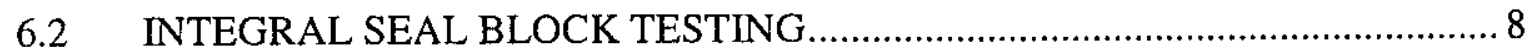

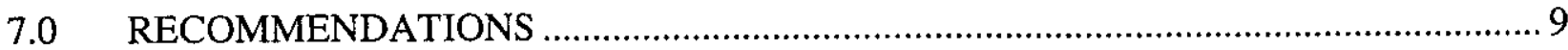

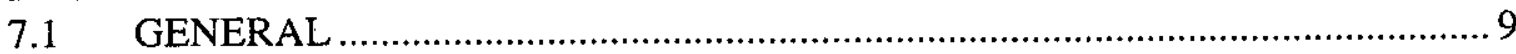

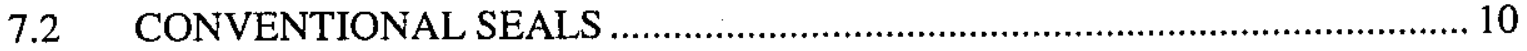

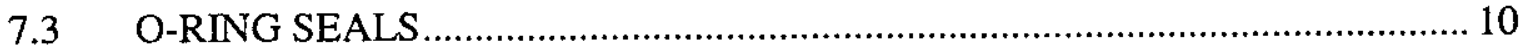

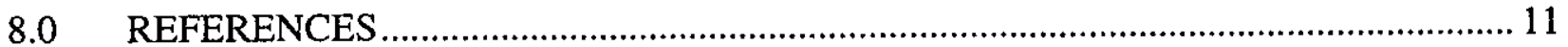

\section{TABLES}

Table 1. General Pressure Requirements. ..................................................................... 3

Table 2. Project Pressure Requirements....................................................................... 4

Table 3. Sealing Verified by Analysis. ......................................................................... 5

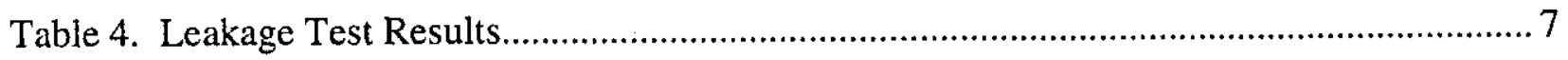




\section{TERMS}

HWVP

ISB

MWTF

PTFE

PUREX

REDOX

WFD

WFDS

WVNS
Hanford Waste Vitrification Plant (B-595 Project)

Integral Seal Block

Multifunction Waste Tank Facility (W-236A Project)

polytetrafluoroethylene

Plutonium-Uranium Extraction (Plant)

Reduction Oxidation (Plant)

Waste Feed Delivery

Waste Feed Delivery Systems (W-521 Project)

West Valley Nuclear Services 


\section{WASTE FEED DELIVERY PUREX PROCESS CONNECTOR DESIGN PRESSURE}

\subsection{INTRODUCTION}

The remotely operated Plutonium-Uranium Extraction (PUREX) connector, which exists in a variety of process and electrical designs, is a component that was developed originally to support radioactive operations in the Reduction Oxidation (REDOX) Plant. Subsequently its application was broadened to include first the PUREX Plant and, more recently, to include tank farm designs. The PUREX connector evolved from the original HANFORD connector developed by Du Pont in the early 1940's. Partly as a consequence of the age of the design, an original analytical/testing history is not available justifying its ultimate design and sealing requirements. The lack of this original "pedigree" documentation is problematical for modern, ongoing projects.

PUREX electrical connector designs are not discussed, although a bibliography is provided for information. A brief history of the connector is provided also.

\subsection{PROBLEM STATEMENT}

Performance requirements of the Phase 1 Waste Feed Delivery (WFD) mission, the initial feed to the Privatization Contractor which concludes in 2018, challenge the design pressure of existing tank farm piping systems and components. The design pressure of both the piping and the components may be exceeded, including the commonly accepted pressure limit of the PUREX process connector $\left(2.76 \mathrm{MPa}\right.$ [400 lb/in ${ }^{2}$ gauge]). This position paper documents the design and historical use of the PUREX connector as a starting point for its use by future projects.

The issue of requalification of the pressure limit for the existing piping, if it is addressed at all, would be the subject of separate work.

\subsection{BACKGROUND}

On several occasions during the last decade, projects have sought analyses that would verify or qualify PUREX connector structural and operating capabilities, including pressure limits. For instance, WHC-SD-W028-FDR-001, Functional Design Criteria, Aging Waste Transfer Lines, Project $W-028$, stipulates a $2.76 \mathrm{~Pa}\left(400 \mathrm{lb} / \mathrm{in}^{2}\right.$ gauge) design pressure requirement for the Project W-028 aging waste transfer piping. During the design phase of this project, however, analyses were not available to demonstrate that the connector (with this capability) would not leak during a seismic event. An Unusual Occurrence Report was written to document this issue (KEH-1991-1051). All the safety analyses that were reviewed assumed failure of the transfer 
lines; therefore, the additional failure of the connector would not change the consequences of the event. The Unusual Occurrence Report was closed, stating that the issue was not an Unreviewed Safety Question.

Because no formally documented analyses were found that evaluated the connector, Project W-028 decided to examine the prestress conditions, the operating conditions, and the leakage characteristics. The $2.76 \mathrm{MPa}$ (400 Ib/in ${ }^{2}$ gauge) system pressure required by Project W-028 was the target design condition addressed in the study, and is likely the reason the most recent conventional wisdom states $2.76 \mathrm{MPa}\left(400 \mathrm{lb} / \mathrm{in}^{2}\right.$ gauge) is the design limit. This work comprises the first known recoverable physical characterization of the remotely operable connector concept since its initial application on the Manhattan Project. The results of this first work are documented in WHC-SD-W028-DA-001, 2 by 2 Inch PUREX Type Jumper Connector Analysis.

For additional information on the capabilities of the PUREX process connector, the reader is directed to additional references. These include analyses and testing broadened to include additional nozzle materials and test conditions conducted on behalf of the Hanford Waste Vitrification Plant (HWVP) Project B-595 documented in WHC-SD-HWV-TRP-004, Jumper Connector Test Report; and WHC-SD-HWV-DCR-002, Analysis of PUREX-Type Jumper Connectors for Hanford Waste Vitrification Plant Use. The analytical history is concluded with the important efforts commissioned by Project W-236A, the Multifunction Waste Tank Facility (MWTF). This work examines the effectiveness of an alternate seal concept as a solution to the high structural loads imposed at assembly and is documented in WHC-SD-W236A-DA-002, Stress Analysis of Integral Seal Block (ISB) Jumper Connectors, and WHC-SD-HWV-TRP-007, PUREX Jumper Connector O-Ring Seal Development.

\subsection{REQUIREMENTS}

\subsection{GENERAL}

The historical records reflect the selection of connector design pressure as being unique to each project. Until recently, the design pressure of the PUREX connector has been held at or below $2.76 \mathrm{MPa}\left(400 \mathrm{lb} / \mathrm{in}^{2}\right.$ gauge). Project connector pressure needs have been documented in Project design criteria, and the integrity has been verified by leak testing during jumper fabrication and startup testing.

Before 1990, PUREX connector hardware for field replacement operations and to support new projects was filled from available spares, which were replaced when inventory quantities fell below established minimums. Documentation for spares replacement contracts was traditionally assembled from approved drawings and specifications, and orders were awarded on a competitive basis. As components of the completed connector assembly arrived on Site and passed receipt inspection, Hanford Fabrication Services shops performed finish machining. The spares inventory was thus restored. This process has been dormant for a decade; however, with the last procurement for connector hardware targeted to fill the needs of West Valley Nuclear 
Services (WVNS) about 1990. The Hanford Site fabricated and tested most of the approximately 225 WVNS jumpers.

Following the WVNS procurement and until recently, the dwindling spares inventory stockpiled in the Hanford $2101 \mathrm{M}$ building has been successful in filling the needs of both new projects and operations. To supplement its needs, Operations has also been able to scavenge PUREX connectors in small quantities from unused preassembled jumpers. The Initial Tank Retrieval Systems Project W-211 and Tank Farms Restoration and Safe Operations Project W-314 have sequestered the available remaining inventory. The spare parts excess has been exhausted.

Operations and a major new WFD project, Waste Feed Delivery Systems (WFDS) Project W-521, which together will require hundreds of connector assemblies, have no inventory to select from. Moreover, the pressure needs of WFDS and companion projects are expected to exceed the aforementioned $2.76 \mathrm{MPa}\left(400 \mathrm{lb} / \mathrm{in}^{2}\right.$ gauge). No design improvements to enhance pressure capability have been made available on any production scale. Some analyses and testing results are available that might support such enhancements, however.

Before enhancements to improve performance capabilities are discussed, it is beneficial to review the traditional requirements in place for more than a decade (see Table 1).

Table 1. General Pressure Requirements.

\begin{tabular}{|c|c|c|}
\hline Design Standard & Conventional Gasket (All sizes) & $\begin{array}{c}\text { Integral Seal Block } \\
\text { (o-ring) }\end{array}$ \\
\hline Jumper Design Standard & No design pressure specified ${ }^{a}$ & Not applicable \\
\hline Jumper Fabrication Specification & $\begin{array}{l}0.69 \mathrm{MPa}\left(100 \mathrm{lbf} / \mathrm{in}^{2} \text { gauge) hydro }\right. \\
\text { unless noted on drawing }\end{array}$ & Not applicable \\
\hline $\begin{array}{l}\text { Tube Jumper Fabrication } \\
\text { Specification }\end{array}$ & $\begin{array}{l}0.69 \mathrm{MPa}\left(100 \mathrm{lbf} / \mathrm{in}^{2} \text { gauge }\right) \\
\pm 0.14 \mathrm{MPa}\left(20 \mathrm{lbf} / \mathrm{in}^{2} \text { gauge }\right) \text { test } \\
\text { pressure }\end{array}$ & Not applicable \\
\hline
\end{tabular}

${ }^{a}$ WHC-SD-RE-DGS-002, 1991, Jumper Design Standard, Westinghouse Hanford Company, Richland Washington.

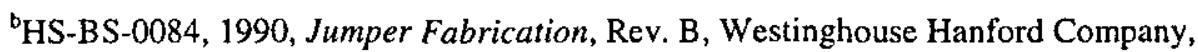
Richland, Washington. (Note: Hydrostatic test pressures are typically specified on jumper drawings.)

'HWS-10284, 1983, Tube Jumper Fabrication (As-amended), Rev. 0, Rockwell Hanford Operations, Richland; Washington.

\subsection{PROJECT-SPECIFIC REQUIREMENTS}

Project-specific pressure requirements are found in a variety of references and are summarized in Table 2. Several projects were planned but were not built (W-028, B-595, and Multifunction Waste Tank Facility [MWTF] Project W-236A), and several key projects are in the design/construction phase (W-21l and W-314). Note that these latter two projects carry the "historical maximum" design pressure $2.76 \mathrm{MPa}$ (400 lbf/in ${ }^{2}$ gauge). 
Table 2. Project Pressure Requirements.

\begin{tabular}{|c|c|c|}
\hline Project & Conventional Gasket & $\begin{array}{l}\text { Integral Seal Block } \\
\text { (o-ring) }\end{array}$ \\
\hline $\begin{array}{l}\text { Aging Waste Transfer Lines } \\
\text { (Project W-028) }\end{array}$ & $\begin{array}{l}\text { Design pressure considered to be } \\
2.76 \mathrm{MPa}\left(400 \mathrm{lbf} / \mathrm{in}^{2} \text { gauge }\right)^{\mathrm{a}}\end{array}$ & Not applicable \\
\hline $\begin{array}{l}\text { Replacement Cross-Site Transfer } \\
\text { System (Project W-058) }\end{array}$ & $\begin{array}{l}2.76 \mathrm{MPa}\left(400 \mathrm{lbf} / \mathrm{in}^{2} \text { gauge }\right) \\
\text { minimum operating pressure }\end{array}$ & $\begin{array}{l}2.76 \mathrm{MPa} \text { (400 lbf/in }{ }^{2} \text { gauge) } \\
\text { minimum operating pressure }\end{array}$ \\
\hline $\begin{array}{l}\text { High-Level Waste Vitrification } \\
\text { Plant (Project B-595) }\end{array}$ & $\begin{array}{l}1.52 \mathrm{MPa}\left(220 \mathrm{lbf} / \mathrm{in}^{2}\right) \text { design } \\
\text { pressure }^{\mathrm{c}}\end{array}$ & Not applicable \\
\hline $\begin{array}{l}\text { Initial Tanks Retrieval Systems } \\
\text { (Project W-211) }\end{array}$ & $\begin{array}{l}2.76 \mathrm{MPa}\left(400 \mathrm{lbf} / \mathrm{in}^{2} \text { gauge }\right) \\
\text { maximum operating pressure }\end{array}$ & Not applicable \\
\hline $\begin{array}{l}\text { Tank Farm Restoration and Safe } \\
\text { Operations (Project W-314) }\end{array}$ & $\begin{array}{l}2.76 \mathrm{MPa}\left(400 \mathrm{lbf} / \mathrm{in}^{2} \text { gauge }\right) \\
\text { design pressure }\end{array}$ & Not applicable \\
\hline $\begin{array}{l}\text { Multifunction Waste Tanks Facility } \\
\text { (Project W-236A) }\end{array}$ & Not applicable & $\begin{array}{l}2.76 \mathrm{MPa}\left(400 \mathrm{lbf} / \mathrm{in}^{2}\right) \text { design } \\
\text { pressure }^{\mathrm{f}}\end{array}$ \\
\hline $\begin{array}{l}\text { Single-Shell Tank 241-C-106 } \\
\text { Sluicing (Project W-320) }\end{array}$ & $\begin{array}{l}2.2 \mathrm{MPa}\left(320 \mathrm{lbf} / \mathrm{in}^{2} \text { gauge }\right) \text { design } \\
\text { pressure }^{\mathrm{g}}\end{array}$ & Not applicable \\
\hline $\begin{array}{l}\text { 241-SY-101 Rapid Rise Mitigation } \\
\text { Project }\end{array}$ & $\begin{array}{l}4.14 \mathrm{MPa}\left(600 \mathrm{lbf} / \mathrm{in}^{2}\right) \text { design } \\
\text { pressure }\end{array}$ & Not applicable \\
\hline $\begin{array}{l}\text { Evaporator Upgrade } \\
\text { (Project B-534) }\end{array}$ & $\begin{array}{l}\text { 4.14 } \mathrm{MPa}\left(600 \mathrm{lbf} / \mathrm{in}^{2}\right) \text { design } \\
\text { pressure }^{\mathrm{j}}\end{array}$ & Not applicable \\
\hline $\begin{array}{l}\text { West Valley Nuclear Services } \\
\text { (WVNS) }\end{array}$ & $\begin{array}{l}0.93 \mathrm{MPa}\left(135 \mathrm{lbf} / \mathrm{in}^{2}\right) \text { maximum } \\
\text { operating pressure }^{\mathrm{k}}\end{array}$ & Not applicable \\
\hline
\end{tabular}

aWHC-SD-W028-DA-001. 1992, Jumper Connector Analysis, 2 by 2 Inch PUREX Type Connector,

Rev. 0, Westinghouse Hanford Company, Richland, Washington.

${ }^{b}$ WHC-SD-W058-FDC-001, 1996, Functional Design Criteria for Project W-058, Replacement of the Cross-Site Transfer System, Rev. 3, Westinghouse Hanford Company, Richland, Washington.

'WHC-SD-HWV-DCR-002, 1994, Analysis of PUREX-Type Jumper Connectors for Hanford Waste Vitrification Plant Use, Rev. 0, Westinghouse Hanford Company, Richland, Washington.

${ }^{\mathrm{d}}$ Drawing H-2-31750, 1991, Piping Material Code, M-25, Rev. 1, Westinghouse Hanford Company, Richland, Washington.

${ }^{\circ}$ HNF-SD-W314-PDS-001, 1998, Project Development Specification for Transfer Piping,

Project W-314, Numatec Hanford Corporation, Richland, Washington.

'WHC-SD-W236A-FDC-001, 1994, Project W-236A Multi-Function Waste Tank Facility, Functional Design Criteria, Rev. 1, Westinghouse Hanford Company, Richland, Washington.

${ }^{8}$ Bailey, J. W., 1998, Project W-320, 241-C-106 Sluicing Construction Specification, W-320-CI, Numatec Hanford Company, Richland, Washington.

${ }^{h}$ HNF-4170, 1999, Specification for SY101 Rapid Mitigation Transfer Pump Piping, Rev. 0, COGEMA Engineering Corporation, Richland, Washington.

'HNF-4360, 1999, 241-SY-101 System Test Reports, Rev. 1, Lockheed Martin Hanford Corporation, Richland, Washington.

${ }^{j}$ Nicholson, J., 2000, Project B-534, Evaporator Upgrade, email message to P. J. Brackenbury, Numatec Hanford Corporation, Richland, Washington. (Note: maximum size parts were selected especially for this application.)

kKochialski, T., 2000, PUREX Connector Design Pressure, email message to P. J. Brackenbury, Numatec Hanford Company, Richland, Washington. 


\subsection{ANALYSES OVERVIEW}

Several informal manual calculations have been recovered from the literary archives pertaining to remotely operated connectors; however, the only formal, comprehensive program of qualification by analysis is summarized in Table 3 and described in the references. Note that the sponsoring organizations had analytical goals differing somewhat from each other and that most of the analytical work focused on the determination of physical load limits in the highest stressed connector components. Determination of the ultimate sealing capability was not of interest, and no design package exists today.

Table 3. Sealing Verified by Analysis.

\begin{tabular}{|c|c|c|}
\hline Project & Conventional Gasket & $\begin{array}{l}\text { Integral Seal Block } \\
\text { (o-ring) }\end{array}$ \\
\hline $\begin{array}{l}\text { Aging Waste Transfer Lines } \\
\text { (Project W-028) }\end{array}$ & $\begin{array}{l}\text { Operating screw load versus } \\
\text { sealing ability at } 2.76 \mathrm{MPa} \\
\left(400 \mathrm{lbf} / \mathrm{in}^{2}\right)^{\mathrm{a}}\end{array}$ & Not applicable \\
\hline $\begin{array}{l}\text { High-Level Waste Vitrification } \\
\text { Plant (Project B-595) }\end{array}$ & $\begin{array}{l}\text { Operating screw load versus } \\
\text { sealing ability at } 1.72 \mathrm{MPa} \\
\left(250 \mathrm{lbf} / \mathrm{in}^{2}\right)^{\mathrm{b}}\end{array}$ & Not applicable \\
\hline $\begin{array}{l}\text { Multifunction Waste Tanks Facility } \\
\text { (Project W-236A) }\end{array}$ & Not applicable & $\begin{array}{l}\text { Operating screw load versus seal } \\
\text { forces at } 2.76 \mathrm{MPa}\left(400 \mathrm{lbf} / \mathrm{in}^{(2)}\right)^{\mathrm{c}}\end{array}$ \\
\hline
\end{tabular}

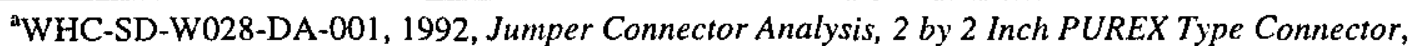
Westinghouse Hanford Company, Richland, Washington.

${ }^{b}$ WHC-SD-HWV-DCR-002, 1994, Analysis of PUREX-Type Jumper Connectors for Hanford Waste Vitrification Plant Use, Rev. 0, Westinghouse Hanford Company, Richland, Washington.

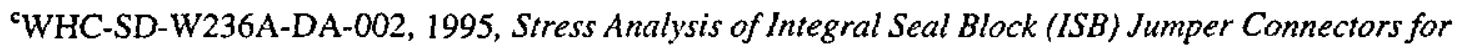
$2 \& 3 \& 4$ Inch Sizes, Rev. 0, Westinghouse Hanford Company, Richland, Washington.

\subsection{AGING WASTE TRANSFER LINES (PROJECT W-028)}

Project W-028 was conceived to upgrade and improve the aging waste transfer system. It would have corrected noncompliant conditions and addressed the need to provide feed to a pretreatment facility and the HWVP. Assuming the use of pure polytetrafluoroethylene (PTFE) gaskets, WHC-SD-W028-DA-001 analyzes stresses and evaluates leakage potential in response to the needs of Project W-028 by:

- Determining the maximum amount of initial preload (torque) that can be applied to 5.08 and $7.6 \mathrm{~cm}$ (2- and 3-in.) PUREX process connectors at the time of installation.

- Determining the maximum allowable load ratings for 5.08 and $7.6 \mathrm{~cm}$ (2- and 3-in.) PUREX process connectors. 
- Investigating the possibility of leakage from 5.08 and $7.6 \mathrm{~cm}$ (2- and 3-in.) PUREX process connectors caused by a seismic event and/or the application of operating loads.

The investigation is purely analytical and determines a satisfactory load on the operating screw that will achieve sealing for an internal pressure of $2.76 \mathrm{MPa}\left(400 \mathrm{lbf} / \mathrm{in}^{2}\right)$. (It is also of interest to note that "the connector will see insignificant seismic forces and will maintain its integrity during a seismic event" (WHC-SD-W028-DA-001).

\subsection{HANFORD WASTE VITRIFICATION PLANT (PROJECT B-595)}

Assuming the use of carbon reinforced PTFE gaskets, WHC-SD-HWV-DCR-002 repeats the process identified in WHC-SD-W028-DA-001 for 5.08, 7.6, and $10.16 \mathrm{~cm}(2-, 3-$ and 4-in.) PUREX process connectors but for materials, pressures, and temperatures relevant to the HWVP design. (Results from the testing of the connector assemblies also were available to make limited comparisons with the analyses [WHC-SD-HWV-TRP-004].)

The operating screw preload, which theory predicts is required to create a successful seal at $1.72 \mathrm{MPa}\left(250 \mathrm{lbf} / \mathrm{in}^{2}\right)$ while not overstressing component parts, was determined for three connector sizes. The "...preload force required for sealing is near the individual component limits for the two-inch connector and above the block limit for the three inch connector" (WHC-SD-HWV-DCR-002). Additional testing and analyses are recommended.

The difficulty in relating the assembly torque to the preload force in the operating screw (which is responsible for creating the seal) is highlighted. This difficulty is key to the emphasis placed on improving the sealing ability of the connector, and is precisely why subsequent testing and analyses were directed at an improved seal design. The o-ring seal concept began to emerge.

\subsection{MULTIFUNCTION WASTE TANK FACILITY (PROJECT W-236A)}

The analyses conducted on behalf of this new tank farm project focused on two-inch, three-inch, four-inch and two-inch three-way connectors with the improved seal. Significant to this design, leakage integrity could be achieved with diminished operating screw forces. This new configuration, called the integral seal block (ISB) design, is evaluated in WHC-SD-W236A-DA-002. The analyses include both axial and nonaxial loading.

The leakage analyses are limited to examining the seating forces resulting from various preloads in the operating screw in the cold and hot condition with an internal pressure of $2.76 \mathrm{MPa}$ $\left(400 \mathrm{lbf} / \mathrm{in}^{2}\right)$. Negative seating forces are found for some preloads that might imply leakage. Testing would be required to confirm this. 


\subsection{TESTING}

Recent laboratory testing under controlled conditions is summarized in Table 4. The referenced literature reports leakage testing with nozzle forces and moments applied. Most leakage and load testing was performed at modestly elevated temperatures 150 to $200^{\circ} \mathrm{C}$ ( 300 to $400^{\circ} \mathrm{F}$ ).

Table 4. Leakage Test Results.

\begin{tabular}{|c|c|c|}
\hline Project & Conventional Gasket & $\begin{array}{l}\text { Integral Seal Block } \\
\text { (o-ring) }\end{array}$ \\
\hline $\begin{array}{l}\text { Aging Waste Transfer Lines } \\
\text { (Project W-028) }\end{array}$ & No test results & Not applicable \\
\hline $\begin{array}{l}\text { Replacement Cross Site Transfer } \\
\text { System (Project W-058) }\end{array}$ & Not applicable & $\begin{array}{l}\text { 4.14 } \mathrm{MPa}\left(600 \mathrm{lbf} / \mathrm{in}^{2}\right) \text { field test } \\
\text { pressure }^{\mathrm{a}}\end{array}$ \\
\hline $\begin{array}{l}\text { High-Level Waste Vitrification } \\
\text { Plant (Project B-595) }\end{array}$ & $\begin{array}{l}\text { No field test results. Lab tested } \\
\text { successfully to } 1.72 \mathrm{MPa} \\
\left(250 \mathrm{lbf} / \mathrm{in}^{2}\right)^{\mathrm{b}}\end{array}$ & Not applicable \\
\hline $\begin{array}{l}\text { Initial Tanks Retrieval Systems } \\
\text { (Project W-211) }\end{array}$ & $\begin{array}{l}\text { Not tested. } 4.14 \mathrm{MPa}\left(600 \mathrm{lbf} / \mathrm{in}^{2}\right) \\
\text { test pressure specified }\end{array}$ & Not applicable \\
\hline $\begin{array}{l}\text { Tank Farm Restoration and Safe } \\
\text { Operations (Project W-314) }\end{array}$ & $\begin{array}{l}\text { Construction in-progress. } \\
4.14 \mathrm{MPa}\left(600 \mathrm{lbf} / \mathrm{in}^{2}\right) \text { test pressure } \\
\text { specified }^{\mathrm{a}}\end{array}$ & Not applicable \\
\hline $\begin{array}{l}\text { Multifunction Waste Tanks Facility } \\
\text { (Project W-236A) }\end{array}$ & Not applicable & $\begin{array}{l}\text { No field test. Lab tested } \\
\text { successfully to } 6.89 \mathrm{MPa} \\
\left(1,000 \mathrm{lbf} / \mathrm{in}^{2}\right)^{\mathrm{d}, \mathrm{e}}\end{array}$ \\
\hline $\begin{array}{l}\text { Single-Shell Tank 241-C-106 } \\
\text { Sluicing (Project W-320) }\end{array}$ & $\begin{array}{l}\text { Field tested successfully to } 3.3 \mathrm{MPa} \\
\left(480 \mathrm{lbf} / \mathrm{in}^{2}\right)^{\mathrm{f}}\end{array}$ & Not applicable \\
\hline $\begin{array}{l}\text { 241-SY-101 Rapid Rise Mitigation } \\
\text { Project }\end{array}$ & $\begin{array}{l}\text { Field tested successfully to } \\
6.21 \mathrm{MPa}\left(900 \mathrm{lbf} / \mathrm{in}^{2}\right)^{8}\end{array}$ & Not applicable \\
\hline $\begin{array}{l}\text { Evaporator Upgrade } \\
\text { (Project B-534) }\end{array}$ & $\begin{array}{l}\text { Field tested successfully to } \\
6.21 \mathrm{MPa}\left(900 \mathrm{lbf} / \mathrm{in}^{2}\right)^{\mathrm{h}}\end{array}$ & Not applicable \\
\hline $\begin{array}{l}\text { West Valley Nuclear Services } \\
\text { (WVNS) }\end{array}$ & $\begin{array}{l}\text { Field test pressure various, but less } \\
\text { than } 2.76 \mathrm{MPa}\left(400 \mathrm{lbf} / \mathrm{in}^{2}\right)^{\mathrm{i}}\end{array}$ & Not applicable \\
\hline
\end{tabular}

"ASME B31.3, 1999, Process Piping, American Society of Mechanical Engineers, New York, New York.

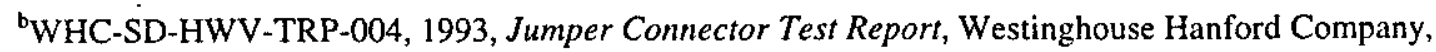
Richland, Washington.

${ }^{c}$ Drawing H-2-31750, 1991, Piping Material Code, M-25, Rev. 1, Westinghouse Hanford Company, Richland, Washington.

${ }^{\mathrm{d}}$ WHC-SD-WM-TRP-223, 1995, MWTF Jumper Connector Integral Seal Block Development and Leak Testing, Rev. 0, Westinghouse Hanford Company, Richland, Washington.

'WHC-SD-HWV-TRP-007, 1994, PUREX Jumper Connector O-Ring Seal Development, Rev. 0, Westinghouse Hanford Company, Richland, Washington.

'HNF-2532, 1998, Project W-320-241-C-106 Sluicing, Construction Specification, W-320-CI, Rev. 0, Numatec Hanford Company, Richland, Washington. 
Table 4. Leakage Test Results.

\begin{tabular}{|c|c|c|}
\hline Project & Conventional Gasket & $\begin{array}{c}\text { Integral Seal Block } \\
\text { (o-ring) }\end{array}$ \\
\hline
\end{tabular}

${ }^{8}$ HNF-4360, 1999 241-SY-I01 System Test Reports, Rev. 1, Lockheed Martin Hanford Company, Richland, Washington.

${ }^{\text {hH}}$ H-2-99026, Sheet 3, 1991, Jumper Assembly (P-B-2) C to 4 \& 5 Pump Discharge, Rev. 1, Kaiser Engineers Hanford Company, Richland, Washington.

'Tomasczewski, T., 2000, "WVNS/PUREX Connector Design Pressure Question," message to P. J. Brackenbury, Numatec Hanford Company, Richland, Washington.

\subsection{CONVENTIONAL SEAL TESTING}

Because of funding limitations, Project W-028 was unable to complete testing to verify the analyses begun on the conventionally sealed (gasketed) 5.08 -cm (2-in.) PUREX connector. Testing was completed on behalf of Project B-595 (HWVP), however, to verify the following:

- The relationship between applied torque and installation preload.

- The sealing characteristics of the carbon-reinforced PTFE gasket with respect to applied torque.

- The analytical predictions and sealing characteristics when subjected to operating loads and service conditions.

\subsection{INTEGRAL SEAL BLOCK TESTING}

A seal design involving the use of o-rings in the place of larger cross-section "conventional" gaskets was conceived to minimize the reported uncertainty in relating the assembly forces and sealing ability. It is possible to create very high assembly forces using the available impact wrenches, and these forces can vary from assembly to assembly. The ISB design is intended to overcome these uncertainties in assembly forces while still creating an effective seal. Integral seal block (ISB) development and leak testing is reported in WHC-SD-HWV-TRP-007and WHC-SD-WM-TRP-223, MWTF Jumper Connector Integral Seal Block Development and Leak Testing. ISB design testing completed on behalf of Project W236A (MWTF) was targeted to verify the following:

- The effect of clamping force on ISB connector integrity.

- The effect of forces and moments on leakage performance of the ISB connector.

- The effect of temperature and pressure on the leakage of the ISB connector.

- The seal compression properties of the o-rings used in the ISB connector.

- Proof testing to (o-ring) failure is reported in WHC-SD-HWV-TRP-007. Leak testing of the 2- and 3-in. ISB design to $13.79 \mathrm{MPa}\left(2000 \mathrm{lbf} / \mathrm{in}^{2}\right.$ gauge) without failure is also reported. There is the potential that all sizes can be shown to perform without leakage to 
RPP-5793 REV 0

13.79 MPa (2000 lbf/in ${ }^{2}$ gauge) subject to additional testing and confirming structural analyses.

\subsection{RECOMMENDATIONS}

\subsection{GENERAL}

Jumpers embodying the conventionally sealed connector should be the first choice for all site applications. This design has a long history of success in remote applications where dimensions may be questionable and the application of assembly stresses by the impact wrench is uncertain. The gasket is forgiving when jumpers must be removed and subsequently replaced for no other reason than to expose the deepest components in valve and pump pits.

A program to prepare the documentation and procure new connector hardware to support the WFD mission should begin immediately. The hardware should be targeted for the spares inventory and be of sufficient quantity to satisfy both operations and project needs through the end of the WFD mission. Recommendations concerning material properties and conditions made in the referenced literature should be observed.

It is widely known and accepted that the current conventional gasket material, PTFE, has poor radiation resistance. Selection of a replacement conventional gasket material should be considered as a component of any future leak-testing program.

Previous testing activities did not attempt to derive factors of safety. One result is that the analytical results, compared with the test results, seem too conservative. In any event, the test and analysis findings all clearly underscore the importance of obtaining specified (expected) material quality to ensure maximum performance capability.

WHC-SD-W236A-DA-002 recommends additional testing, analyses, and design modifications. While the recommendations do not bear directly on the current interest in elevating the design sealing pressures, they should be revisited during the process of developing a program for replacement connector hardware.

The available analyses and testing do not qualify the connector hardware to be leak tight during and after a design basis earthquake. If this becomes a requirement of the WFD Program, the connector assembly would have to be seismically qualified for operability and nonleakage. This could be done readily by additional analysis and testing, using the existing work in WHC-SD-W236A-DA-002) as a starting point. 
Procedures for assembly of the connector should reflect the correct assembly sequence and lubrication. For example, to prevent galling, the operating screw and screw/block mating surfaces should be lubricated with a light coating of Nickel Never Seize. ${ }^{l}$

The quantity and availability of satisfactory impact wrenches should be verified. Deficiencies identified in this area should be corrected immediately. Consideration should be given to a hydraulically powered wrench design, supplanting the conventional electric design, which is no longer manufactured. (A specification, W-314-P10, Procurement Specification for Hydraulic Wrench/Power Pack, is available to support the hydraulic wrench design).

\subsection{CONVENTIONAL SEALS}

A design pressure of $2.76 \mathrm{MPa}\left(400 \mathrm{lbf} / \mathrm{in}^{2}\right)$ for the conventionally sealed connector in all sizes has been and remains the norm. 'Under these circumstances, hydrostatic test conditions to 4.14 MPa (600 lbf/in $\left.{ }^{2}\right)(1.5$ times design per ASME B31.3) is the expected ultimate sealing pressure.

Test pressures of 6.21 MPa $\left(900 \mathrm{lbf} / \mathrm{in}^{2}\right)$ were documented for both Project B-534, an evaporator upgrade, and in the 241-SY-101 Rapid Rise Mitigation Project. In the B-534 Project, connector components at the largest dimensional extreme were selected for the few connectors expected to see the elevated test pressure. These connectors subsequently passed hydrostatic testing. In the Rapid Rise Project, four conventionally sealed PUREX connectors (three $5.08 \mathrm{~cm} \mathrm{(2} \mathrm{in.)} \mathrm{and} \mathrm{one}$ $7.6 \mathrm{~cm}$ ( $3 \mathrm{in}$.) also were successfully tested to $6.21 \mathrm{MPa}\left(900 \mathrm{lbf} / \mathrm{in}^{2}\right)$ without leakage. Based upon this experience and pending verification by additional tests and/or analyses, a design pressure of $4.14 \mathrm{MPa}\left(600 \mathrm{lbf} / \mathrm{in}^{2}\right)$ and a test pressure of $6.21 \mathrm{MPa}\left(900 \mathrm{lbf} / \mathrm{in}^{2}\right)$ for conventionally sealed connectors in these two sizes should be achievable.

Proof testing the conventionally sealed PUREX connector has not been performed. Consequently, sealing capability in excess of $6.21 \mathrm{MPa}\left(900 \mathrm{lbf} / \mathrm{in}^{2}\right)$ must also be demonstrated in the laboratory. A simple test program should be instituted to explore the effectiveness of the conventional gasket at pressures in excess of $6.21 \mathrm{MPa}\left(900 \mathrm{lbf} / \mathrm{in}^{2}\right)$. The torque-to-load relationships discussed in WHC-SD-HWV-DCR-002 and WHC-SD-W236A-DA-002 should be consulted to avoid overloading component parts. Resources permitting, consideration of a replacement material for $\mathrm{PTFE}$, one with greater radiation resistance, may be included as part of this program.

\subsection{O-RING SEALS}

Two-inch, three-inch, four-inch and two-inch three-way connectors were successfully tested at $6.89 \mathrm{MPa}\left(1,000 \mathrm{lbf} / \mathrm{in}^{2}\right)$ and 150 to $200^{\circ} \mathrm{C}\left(300\right.$ to $\left.400^{\circ} \mathrm{F}\right)$ with o-rings of various materials

under laboratory conditions. Subsequently, after design modifications to the o-ring groove, the o-ring sealed connector design demonstrated successful sealing ability to modestly elevated

\footnotetext{
${ }^{1}$ Trademark of Bostik Emhart, Broadview, IL
} 


\section{RPP-5793 REV 0}

pressures in Project W-058, its only application. Elements of WFD projects that must carry a design pressure in excess of $4.14 \mathrm{MPa}\left(600 \mathrm{lbf} / \mathrm{in}^{2}\right)$ should apply the o-ring seal unless testing has demonstrated the sealing ability of the conventional gasket to pressures in excess of 6.21 MPa $\left(900 \mathrm{lbf} / \mathrm{in}^{2}\right)$.

\subsection{REFERENCES}

ASME B31.3, 1999, Process Piping, American Society of Mechanical Engineers, New York, New York.

Bailey, J. W., 1998, Project W-320, 241-C-106 Sluicing Construction Specification, W-320-C1, Numatec Hanford Company, Richland, Washington.

Drawing, H-2-31750, 1991, Piping Material Code, M-25, Rev. 1, Westinghouse Hanford Company, Richland, Washington.

Drawing, H-2-99026, Sheet 3, 1991, Jumper Assembly (P-B-2)C to 4 and 5 Pump Discharge, Rev. 1, Kaiser Engineers Hanford Company, Richland, Washington

HNF-4170, 1999, Specification for SY-101 Rapid Mitigation Transfer Pump Piping, Rev. 0, COGEMA Engineering Corporation, Richland, Washington.

HNF-4360, 1999, 241-SY-101 System Test Reports, Lockheed Martin Hanford Corporation, Richland, Washington.

HNF-SD-W314-PDS-001, 1999, Project Development Specification for Transfer Piping, Project W-211, Rev. 2, Numatec Hanford Corporation, Richland, Washington.

HS-BS-0084, Jumper Fabrication, Rev. B, Westinghouse Hanford Company, Richland, Washington.

HWS-10284., 1981, Tube Jumper Fabrication, Rockwell Hanford Operations, Richland, Washington.

KEH-1991-1051, 1991, Possible Insufficient Seismic Analysis of Piping Jumper, Occurrence Report, Kaiser Engineers Hanford Company, Richland, Washington.

Kochialski, T., 2000, "PUREX Connector Design Pressure," message to P. J. Brackenbury, Numatec Hanford Company, Richland, Washington.

Tomasczewski, T., 2000, "WVNS/PUREX Connector Design Pressure Question," message to P. J. Brackenbury, Numatec Hanford Company, Richland, Washington.

W-314-P10, 1999, Rev 0, Procurement Specification for Hydraulic Wrench/Power Pack, Fluor Daniel Northwest for Fluor Daniel Hanford, Richland, Washington 
WHC-SD-HWV-DCR-002, 1994, Analysis of PUREX-Type Jumper Connectors for Hanford Waste Vitrification Plant Use, Rev. 0, Westinghouse Hanford Company, Richland, Washington.

WHC-SD-HWV-TRP-004, 1993, Jumper Connector Test Report, Rev. 1, Westinghouse Hanford Company, Richland, Washington.

WHC-SD-HWV-TRP-007, 1994, PUREX Jumper Connector O-Ring Seal Development, Rev. 0, Westinghouse Hanford Company, Richland, Washington.

WHC-SD-RE-DGS-002, 1991, Jumper Design Standard, Rev. 3, Westinghouse Hanford Company, Richland, Washington.

WHC-SD-W028-DA-001, 1992, 2 by 2 Inch PUREX Type Jumper Connector Analysis, Rev. 0, Westinghouse Hanford Company, Richland, Washington.

WHC-SD-W028-FDR-001, 1987, Functional Design Criteria, Aging Waste Transfer Lines, Project W-028, Westinghouse Hanford Company, Richland, Washington.

WHC-SD-W058-FDC-001, 1996, Functional Design Criteria for Project W-058, Replacement of the Cross-Site Transfer System, Rev. 3, Westinghouse Hanford Company, Richland, Washington.

WHC-SD-W236A-DA-002, 1995, Stress Analysis of Integral Seal Block (ISB) Jumper Connectors, Rev. 0, Westinghouse Hanford Company, Richland, Washington.

WHC-SD-W236A-FDC-001, 1993, Functional Design Criteria, Multi-Function Waste Tank Facility, Westinghouse Hanford Company, Richland, Washington.

WHC-SD-WM-TRP-223, 1995, MWTF Jumper Connector Integral Seal Block Development and Leak Testing, Rev. 0, Westinghouse Hanford Company, Richland, Washington. 


\section{APPENDIX}

\section{HISTORY}

Among the many challenges to be surmounted before the success of the Manhattan Project could be ensured were a number of needed technology developments. In a classic of build-beforedesign, the construction of the processing buildings-canyons-began even before the selection of the chemistry of the processes they would house. The novel technology developments to permit this approach included the idea of the canyon with individual cells, the remotely operated crane with attached impact wrench, and moveable pipe with the remotely operable connector attached.

The Plutonium Uranium Extraction (PUREX) process connector (a variant of the original HANFORD connector originally developed by Du Pont) was first referred to as the REDOX connector. Kellex and Vitro Engineering developed it during the design and construction of the Reduction and Oxidation (REDOX) plant, which began operations in 1953.

The REDOX connector differs from the flat-faced HANFORD connector used in the T, U, and B plants and at the Savannah River Site in the configuration of the seal face. The somewhat spherically faced seal configuration in the PUREX connector evolved to accommodate process vessel thermal movement. A Denver, Colorado company was the manufacturer of the original quantity of REDOX (PUREX-type) connectors.

The original connector, like the most recent, was comprised of both castings and forgings. In the early connector, cast parts were rough sand castings. In the recent past, however, cast parts have become precision investment castings. This process improved both the dimensional and the structural characteristics of the resultant parts. Several parts of the original connector were made of carbon steel (hooks, tie rods, etc.) but these were found to corrode in the cell environment. Improved corrosion performance was sought from the beginning.

The first nozzles were manufactured from ordinary austenitic stainless steels. Nozzle seal surfaces manufactured from these comparatively soft materials were later hard faced with Stellite $^{2}$ to resist impact damage from items suspended by the canyon crane. Different materials were adopted in the mid-1960's to obtain additional strength to resist clamp loads and because hard facing caused sensitivity to corrosion. The successor materials included ALMAR $362^{3}$ (Rockwell Hanford Operations experienced fractures with this material when improperly heattreated) and the cast duplex stainless steel CD4MCu. The original CD4MCu material was centrifugally cast. (Tests were made on Hastelloy ${ }^{4}$ and titanium nozzle materials as well. These tests included determining the effects of overimpacting with the impact wrench and measuring

\footnotetext{
${ }^{2}$ Stellite is a trademark of Deloro Stellite Company.

${ }^{3}$ ALMAR is a trademark of Allegheny Ludlum.

${ }^{4}$ Hastelloy is a trademark of Haynes International.
} 
damage caused by collisions of knife-edges with the nozzle seal surface.) Improved structural capability also was sought from the beginning.

In the early 1980's quality assurance requirements were refined and applied to the connector and connector parts as never before. At that time both Tank Farms and PUREX shared the cost and effort for purchasing and design of the connector. About this time, sand casting was abandoned and investment casting began to be used. Also, tight tolerances were adopted, and emphasis was placed on maintaining dimensional uniformity to ensure parts interchangeability. Suppliers had a more difficult time satisfying dimensional requirements. When interchangeability came along, it became easy to change out components when they failed.

At the conclusion of their association with the Hanford Site, the original suppliers offered their shop drawings to the Hanford contractor, but the drawings were refused. Subsequently, the experience has been that one manufacturer may interpret the connector drawings differently from another and the resultant shop drawings he makes will be different from those another manufacturer may make. This tendency does not enhance interchangeability. For instance, the PUREX plant was built to the shop Drawings of Blaw-Knox, and the operators had difficulty reconciling the finished plant with the Vitro design drawings.

As the drawings evolved, sometimes the material specifications were not perfectly consistent with drawing requirements. For instance, the drawing may have called for an ASTM A743 Type $\mathrm{CD} 4 \mathrm{MCu}$ and specified a finished hardness for the part that differed from the latest issue of the specification. After the inconsistency was noticed, appropriate variance paperwork was created and subsequently approved.

The original PUREX connector units were supplied as complete assemblies, not in parts and pieces. The most recent contract for connector components was for purchase of hardware on a parts and pieces basis to support fabricating West Valley Nuclear Services (WVNS) jumpers. The contract for castings was placed with POST PRECISION PRODUCTS, a small Class III casting "house" in Strausstown, Pennsylvania. Larger, more capable firms had expressed interest in the contract but they were not cost competitive. For instance, in the bidding process PED, a Class I casting "house" in Oregon City, Oregon, was $300 \%$ over POST PRECISION.

The original contract required POST PRECISION to create a Class I+ product but after three years of difficulty, they asked to be relieved of their contractual obligation. They eventually agreed to finish some of the remaining parts, but not all. Hooks, for instance, they did not complete. Deliveries became sporadic and parts received and inspected in Product Quality Services in the 1163 Building with a three-axis coordinate measurement machine had a fairly high rejection rate. In the end, it became almost the standard to send their finished parts out for remachining before assembling them into the finished WVNS jumpers. Approximately 225 WVNS jumpers were fabricated under the supervision of Hanford personnel in Hanford shops. As an expedient near the end of the effort, approximately 25 additional jumpers were fabricated under the supervision of WVNS personnel in the Portland, Oregon vicinity.

Some original casting molds from earlier procurements still exist in the Hanford spare parts inventory. The process of making casting molds is very expensive and can easily cost more than the finished part, with the process being proprietary from vendor to vendor. Using the WVNS 
experience as a basis, a new contract for this hardware will require $21 / 2$ to 3 years from the date of the order to the first article acceptance.

A limited quantity of o-ring sealed connector blocks, machined from wrought material, were fabricated for Project W-058 in the 200 Area machine shops in the late 1996 to early 1997 time period. The exact quantity of this design installed in SY-A, SY-B and the 244-A lift station is only twenty. The majority of the connectors were conventionally sealed and all in the supernatant transfer system. This is the only known application of the o-ring design, and it was not without some difficulty. The rectangular o-ring groove would not hold the rings. A half dovetail groove was added to the blocks and the fabrication, installation and testing then proceeded to completion. The poor o-ring fit was not only understood, but also anticipated by the designers. The solution lies in dimensioning the o-ring and the groove to ensure a successful union of the two parts. This was not done in the W-058 work because of the limited number of assemblies involved.

\section{BIBLIOGRAPHY}

\section{Process Connectors}

Byers, H. H., and Ruff, E. S., 1992, Machining of Jumper Connector Nozzles from Hastelloy C-22 Nickel Alloy, 304L Stainless Steel and ULTIMET Cobalt Alloy, WHC-SD-HWV-TRP-003, Rev. 0, Westinghouse Hanford Company, Richland, Washington.

Dempster, J., 1991, "Stress Analysis of 2" Nozzle for Decon Station," WVNS-CAL-.012, ER Number 2115 (hand calculation), West Valley Nuclear Services, West Valley, New York.

Dempster, J. 1991, "Stress Analysis of 2" Titanium Nozzle," WVNS-CAL-016, ER Number 2115, (hand calculation), West Valley Nuclear Services, West Valley, New York.

Hibbard, R. L., 1992, "Fabrication Services Technical Procedure, PUREX Connector Assemblies," FS-F-14, Westinghouse Hanford Company, Richland, Washington.

Kingsley, P., 1965, "Investigation of CD4MCu as a Hanford Male Connector (Nozzle) Material,” RE-SEP-508, General Electric, Metallurgy, Facilities Engineering Operation, Chemical Processing Department, Richland, Washington.

Koontz, W. H., 1965, "Specification of Cast Stainless Steel Precipitation Hardening Alloy For Use In Remote Connector Nozzles," HWS-7378General Electric, General Plant \& Utilities Engineering Section, Richland, Washington.

Kratzer, M., 1991, “2 Inch (Titanium) Nozzle Connector Analysis, Job No. 0336,” (hand calculation), Industrial Alloy Fabricators, Inc., Forest Grove, Oregon.

Kratzer, M., 1991, “2 x 3 Inch (Titanium) Nozzle Connector Analysis, Job No. 0336,” (hand calculation), Industrial Alloy Fabricators, Inc.; Forest Grove Oregon. 
Kratzer, M., 1991, "3 Inch (Titanium) Nozzle Connector Analysis, Job No. 0336," (hand calculation), Industrial Alloy Fabricators, Inc., Forest Grove Oregon.

McDonnel, G., "Report on Stainless ACI Grade CD4MCu Male Jumper Connectors," General Electric, Richland, Washington.

Pan, R. B., 1983, "Stress Analyses of Jumper Connector Parts," SD-RE-TI-102, Rockwell Hanford Operations, Richland, Washington.

Siemens, D. H., et al., 1985, "High Level Radioactive Waste Vitrification Process Equipment Component Testing," PNL-5394/UC-70, Pacific Northwest Laboratory, Richland, Washington.

Stone, J., 1987, "242-A Building Evaporator Crystallizer Upgrade, 2 Inch Connector Head Analysis," Project B-534, letter report, Kaiser Engineers Hanford, Richland, Washington.

Walker, W. L., 1961, "Corrosion Test on ESCO 37PH Connector," letter report (no number) to G. L. McDonnell, General Electric, Development \& Corrosion Chemistry Section, Richland, Washington.

Wodrich, D. D., 1958, "Report on Titanium Process Connector Development," HW-58361, General Electric, Process Design and Development, Facilities Engineering Operation, Chemical Processing Department.

\section{Electrical/Instrumentation Connectors}

Bender, R. M., 1992, Electrical Evaluation of Proposed HWVP Connectors, WHC-SD-HWVES-043, Westinghouse Hanford Company, Richland, Washington.

Drawing No. H-2-76956, Sheet 1-4, "PFMP Electrical Connector," Westinghouse Hanford Company, Richland, Washington.

Drawing No. H-2-77337, Sheet 1-3, "PUREX Electrical Connector, 4 Pin \& 20 Pin Assembly \& Details," Westinghouse Hanford Company, Richland, Washington.

Drawing No. H-2 77338, "PUREX Electrical Connector, Instrumentation 33 Pin Assembly \& Details," Westinghouse Hanford Company, Richland, Washington.

Heckendorn, F. M. II, 1983, Instrumentation and Power Jumpers (DWPF), DP-1652 (V0000125), E. I. du Pont de Nemours, Aiken, South Carolina.

Hertzel, L. S., 1984, PFM Electrical Connection Study, SD-PFM-S-001, Westinghouse Hanford Company, Richland, Washington.

Hyde, L. L., 1992, Stress Analysis of HWVP 7 Pin (230 AMP) Electrical Connector Insulating Plates, LLH-23450-92-004, Westinghouse Hanford Company, Richland, Washington. 
Hyde, L. L., 1992, Stress Analysis of HWVP 4, 20 \& 33 pin Electrical Connector Insulating Plates, LLH-23450-92-005, Westinghouse Hanford Company, Richland, Washington.

WHC-SD-HWV-ER-006, Insulating Plates for Hanford Waste Vitrification Plant Electrical Jumper Connectors, Westinghouse Hanford Company, Richland, Washington.

WHC-SD-HWV-ES-043, 1992, Electrical Evaluation of Proposed HWVP Connector, Rev. 0, Westinghouse Hanford Company, Richland, Washington.

WHC-SD-HWV-ES-044, Electrical Evaluation of Proposed HWVP Connectors, Westinghouse Hanford Company, Richland, Washington.

Wilson, C. E., 1985, Chemical Cell Remote Electrical Connector Test Plan, SD-PFM-DTP-006, Westinghouse Hanford Company, Richland, Washington.

Wilson, C. E., 1985, Modified PUREX Electrical Connector Report, SD-PFM-TRP-010, Westinghouse Hanford Company, Richland, Washington. 
RPP-5793 REV 0 


\section{DISTRIBUTION SHEET}

To

Distribution

\section{Project Title/Work Order}

Waste Feed Delivery Systems, PUREX Process Connector Design Pressure

From

RPP Retrieval Engineexing
Name

WL Adams

JE AlIison

JJ Badden

DG Baide

JW Bailey

RM Boger

DE Bowers

JR Biggs

KA Boes

SR Briggs

PJ Brackenbury

CB Bryan

AB Carlson

PJ Certa

AE Choho

JR Collins

TJ Conrads

EJ Cruz

JJ Davis

C Defigh-Price

GC Deweese

RA Dodd

GP Duncan

WJ Eischens

BG Erlandson

AH Eriberg

JD Galbraith

JS Garfield

JL Gilbert

GN Hanson

JP Harris III

WM Hartey, Jr.

\begin{tabular}{c|c|c|c|c} 
MSIN & $\begin{array}{c}\text { Text } \\
\text { With All } \\
\text { Attach. }\end{array}$ & Text Only & $\begin{array}{c}\text { Attach./ } \\
\text { Appendix } \\
\text { Only }\end{array}$ & $\begin{array}{c}\text { EDT/ECN } \\
\text { Only }\end{array}$ \\
\hline
\end{tabular}

$56-15$

R3-72

S5-07

S5-05

R3-25

S7 -12

S5-13

$57-70$

R3-86

R3-47

R3-73

R2-58

R3-73

R3-73

R3-73

G3-11

R3-73

H6-06

H $6-60$

$\mathrm{R} 2-12$

R3-73

R3-72

R3-72

$\mathrm{R} 3-75$

$\mathrm{R} 1-51$

R3-83

R3-73

R3-73

R3-25

R3072

$\mathrm{R} 1-49$

S5-13
Page 1 of 3

Date 4-6-00

EDT No. EDT 628455

ECN No N/A

\begin{tabular}{|l|l|l|l|}
$x$ & & & \\
$x$ & & & \\
\hline
\end{tabular}




\section{DISTRIBUTION SHEET}

To

Distribution

Project Title/Work Order

Waste Feed Delivery Systems, PUREX Process Connector Design Pressure

From

RPP Retrieval Engineering
Name

JL Henderson

TL Hissong

HR Hopkins II

JS Huisingh

JW Hunt

DL Isakson

JM Isdell

LJ Julyk

TJ Kelley

$\mathrm{NW}$ Kirch

PF Kison

JT Koberg

MR Koch

RE Larson

CE Leach

JW Lentsch

GE Maiden

ME McKinney

GW Mclellan

JR Nicholson

EM Nordquist

TL Ostrander

TC oten

RJ Parazin

MA Payne

RS Popielarczyk

RW Powell

WJ Powell

RE Raymond

DW Reberger

CJ Rice

CA Rieck

\section{MSIN}

G3-11

$57-20$

$\mathrm{R} 2-58$

$\times 3-85$

$\mathrm{R} 2-12$

$\mathrm{T} 2-10$

$\mathrm{T} 2-10$

R3-83

$57-83$

R2-11

T4-07

S8-06

S7 -24

T4-07

R3-25

$\mathrm{T} 2-10$

R3-47

R3-47

A3-04

R3-47

T2-10

R3-83

S5-09

H6-63

$\mathrm{R} 2-58$

R3-75

S5-13

$57-70$

$55-13$

$\mathrm{R} 2-53$

R3-47
$\mathrm{R} 1-44$
Page 2 of 3

Date 4-6-00

EDT No. EDT 628455

ECN No. N/A

\section{Text $\quad$ Attach./} With All Text Only Appendix EDT/ECN Attach. Only 


\section{DISTRIBUTION SHEET}

To

Distribution

Waste Feed Delivery Systems, PUREX Process Connector Design Pressure

From

RPP Retrieval Engineering
Project Title/Work Order

\begin{tabular}{|c|c|c|c|c|c|}
\hline \multicolumn{6}{|c|}{ ECN No. N/A } \\
\hline Name & MSIN & $\begin{array}{l}\text { Text } \\
\text { With All } \\
\text { Attach. }\end{array}$ & Text Only & $\begin{array}{c}\text { Attach.l } \\
\text { Appendix } \\
\text { Only }\end{array}$ & $\begin{array}{c}\text { EDT/ECN } \\
\text { Only }\end{array}$ \\
\hline RW Root & $R 2-53$ & $\mathrm{x}$ & & & \\
\hline MJ Schliebe & I6-13 & $\mathrm{x}$ & & & \\
\hline DH Shuford & $\mathrm{S} 7-70$ & $\mathrm{x}$ & & & \\
\hline DM Squiex & L6-13 & $\mathrm{x}$ & & & \\
\hline RT Steen & G3-11 & $\mathrm{x}$ & & & \\
\hline MJ Sutey & $S 5-07$ & $\mathrm{x}$ & & & \\
\hline WT Thompson & R3-73 & $x$ & & & \\
\hline KS Tollefson & $\mathrm{R} 1-51$ & $x$ & & & \\
\hline TA Tomaszewski & $\mathrm{T} 4-52$ & $x$ & & & \\
\hline RL Treat & H6-19 & $x$ & & & \\
\hline RP Tucker & R3-72 & $x$ & & & \\
\hline JE Van Beek & $\mathrm{R} 3-47$ & $\mathrm{x}$ & & & \\
\hline KA White & $\mathrm{R} 3-47$ & $\mathrm{x}$ & & & \\
\hline DD Wiggins & $57-47$ & $\mathrm{x}$ & & & \\
\hline WL Willis & R3-73 & $\mathrm{x}$ & & & \\
\hline U. S. Department of Energy & & & & & \\
\hline Richland Operations office & & & & & \\
\hline Public Reading Room & $\mathrm{H} 2-53$ & $x$ & & & \\
\hline Pacific Northwest National Laboratory & & & & & \\
\hline Hanford Technical Library & $\mathrm{P} 8-55$ & $\mathrm{x}$ & & & \\
\hline HND/ARES Corporation, 636 Jadwin Ave., & & & & & \\
\hline Suite B, Richland, WA 99352 (4) & & $\mathrm{x}$ & & & \\
\hline Cogema Engineering (4) & $\mathrm{H} 3-27$ & $\mathrm{x}$ & & & \\
\hline Parsons Infrastructure \& Tech. Group (4) & B6-01 & $x$ & & & \\
\hline MACTEC, Inc. (4) & $\mathrm{G} 1-42$ & $\mathrm{x}$ & & & \\
\hline Lockheed Martin Services, Inc. & & & & & \\
\hline Central Files & $\mathrm{B} 1-07$ & $x$ & & & \\
\hline Document Processing Center & A3-94 & $x$ & & & \\
\hline
\end{tabular}

Page 3 of 3

Date $4-6-00$

EDT No. EDT 628455

NOA 628455

CN No. N/A \begin{tabular}{l|l|l}
$\begin{array}{l}\text { With All } \\
\text { Attach. }\end{array}$ & Text Only & $\begin{array}{c}\text { Appendix } \\
\text { Only }\end{array}$ \\
\hline
\end{tabular}

T/ECN

Only 